Chirurgia (2017) 112: 673-682

No. 6, November - December

Copyright@ Celsius

http://dx.doi.org/10.21614/chirurgia.112.6.673

\title{
Resection of Concomitant Hepatic and Extrahepatic Metastases from Colorectal Cancer - A Worthwhile Operation?
}

\author{
Andrei Diaconescu', Sorin Alexandrescu', Zenaida Ionel', Cristian Zlate', Razvan Grigorie', Vladislav Brasoveanu', \\ Doina Hrehoret', Silviu Ciurea', Florin Botea', Dana Tomescu'², Gabriela Droc'2, Adina Croitoru³, Vlad Herlea4, \\ Mirela Boros ${ }^{5}$, Mugur Grasu ${ }^{5}$, Radu Dumitru ${ }^{5}$, Mihai Toma ${ }^{5}$, Mihnea Ionescu' ${ }^{1}$, Catalin Vasilescu', Irinel Popescu \\ "Dan Setlacec" Centre of General Surgery and Liver Transplantation, Fundeni Clinical Institute, Bucharest, Romania \\ ${ }^{2}$ Centre of Anaesthesiology and Intensive Care, Fundeni Clinical Institute, Bucharest, Romania \\ ${ }^{3}$ Department of Oncology, Fundeni Clinical Institute, Bucharest, Romania \\ ${ }^{4}$ Department of Pathology, Fundeni Clinical Institute, Bucharest, Romania \\ ${ }^{5}$ Department of Radiology, Fundeni Clinical Institute, Bucharest, Romania
}

\section{Corresponding author:}

Sorin Tiberiu Alexandrescu, MD, PhD

"Dan Setlacec" Centre of General

Surgery and Liver Transplantation

Fundeni Clinical Institute, Bucharest

Romania

Soseaua Fundeni, Nr. 258, Sector 2

Bucharest, 022528, Romania

E-mail: stalexandrescu@yahoo.com

\section{Abbreviations:}

CRC - Colo-rectal cancer

CHMs - Liver-only colorectal

cancermetastases

CEMs - Colorectal extrahepatic metastases

CHEHMs - Colorectal hepatic and

extrahepatic metastases

OS - Overallsurvival

\section{Rezumat \\ Rezectia metastazelor concomitente hepatice și extrahepatice ale cancerul colorectal - o operatie justificată?}

Introducere: Beneficiul rezecției hepatice în cazul metastazelor hepatice şi extrahepatice colorectale (MHEHCR) este încă discutabil. Scopul acestui studiu este de a evalua rezultatele rezectiei metastazelor hepatice şi extrahepatice efectuate pacientilor cu MHEHCR într-un centru medical cu un volum mare de intervenții chirurgicale, atât în sfera chirurgiei hepato-biliare, cât şi în sfera chirurgiei colo-rectale şi de a identifica factorii de prognostic care se corelează cu o supraviețuire îndelungată.

Metoda: Studiul este unul retrospectiv şi se bazează pe un lot de 678 de pacienți consecutivi, cu metastaze hepatice ale cancerului colo-rectal operate într-un singur centru chirurgical, în perioada aprilie 1996 - martie 2016. Dintre aceştia, 73 de pacienți au prezentat MHEHCR. Analiza univariată a fost efectuată pentru identificarea acelor factori de risc ce influențează supraviețirea generală (SG) .

Rezultate: $\mathrm{Au}$ fost 20 de metastaze extrahepatice localizate la nivelul pediculului hepatic, 20 la nivel peritoneal, 12 la nivel ovarian şi pulmonar, $9 \mathrm{cu}$ alte localizări şi 12 recidive locale. Au fost efectuate 53 de rezecții curative (RO). Supraviețuirea 
comparativă între lotul pacienților cu MHEHCR şi cel al pacienților cu metastaze strict hepatice a arătat o diferență semnificativă statistic în favoarea celui de-al doilea lot $(p<0,0001)$, acelaşi rezultat fiind înregistrat şi în prezența rezecției $R 0$ în cele două loturi $(p<0,0001)$. În grupul MHEHCR, SG a fost semnificativă statistic mai mare la pacienții care au beneficiat de rezecție R0 față de cei la care rezecția a fost R1/R2 $(p=0,004)$. Analiza univariată a identificat trei variabile drept factori de prognostic negativ pentru SG: 4 sau mai multe metastaze hepatice, efectuarea unei hepatectomii majore şi perioada realizării rezecției hepatice (1996-2004). Localizarea ovariană sau pulmonară a metastazelor extrahepatice este corelată cu cea mai bună rată de supraviețuire dintre toate localizările posibile dar fară a fi semnificativă statistic.

Concluzie: La pacienții cu metastaze hepatice şi extrahepatice concomitente, rezecția completă (R0) a acestora prelungeşte în mod semnificativ supraviețuirea. Pacienții cu mai puțin de 4 metastaze hepatice, a căror rezecție este realizată printr-o hepatectomie minoră sunt cei care beneficiază cel mai mult de pe urma acestei conduite terapeutice onco-chirurgicale agresive.

Cuvinte cheie: metastaze hepatice ale cancerului colo-rectal, metastaze extrahepatice, metastaze hepatice şi extrahepatice ale cancerului colo-rectal, rezecție hepatică, supraviețuire generală, factori de prognostic

\section{Abstract}

Background: The benefit of hepatic resection in case of concomitant colorectal hepatic and extrahepatic metastases (CHEHMs) is still debatable. The purpose of this study is to assess the results of resection of hepatic and extrahepatic metastases in patients with CHEHMs in a high-volume center for both hepatobiliary and colorectal surgery and to identify prognostic factors that correlate with longer survival in these patients.

Method: It was performed a retrospective analysis of 678 consecutive patients with liver resection for colorectal cancer metastases operated in a single Centre between April 1996 and March 2016. Among these, 73 patients presented CHEHMs. Univariate analysis was performed to identify the risk factors for overall survival (OS) in these patients.

Results: There were $20 \mathrm{CHMs}$ located at the lymphatic node level, 20 at the peritoneal level, 12 at the ovary and lung level, 12 presenting as local relapses and 9 other sites. 53 curative resections (R0) were performed. The difference in overall survival between the CHEHMs group and the CHMs group is statistically significant for the entire groups $(p<0.0001)$, as well as in patients who underwent R0 resection $(\mathrm{p}<0.0001)$. In CHEHMs group, the OS was statistically significant higher in patients who underwent $\mathrm{R} 0$ resection vs. those with $\mathrm{R} 1 / \mathrm{R} 2$ resection $(\mathrm{p}=0.004)$. Three variables were identified as prognostic factors for poor OS following univariate analysis: 4 or more hepatic metastases, major hepatectomy and the performance of operation during first period of the study (1996-2004). There was a tendency toward better OS in patients with ovarian or pulmonary location of extrahepatic disease, although the difference was not statistically significant.

Conclusion: In patients with concomitant hepatic and extrahepatic metastases, complete resection of metastatic burden significantly prolong survival. The patients with up to 4 liver metastases, resectable by minor hepatectomy benefit the most from this aggressive onco-surgical management.

Key words: Colorectal liver metastasis, extrahepatic metastases, hepatic and extrahepatic colorectal metastases,liver resection, overall survival, risk factors 


\section{Introduction}

Colorectal cancer (CRC) ranks third among adult cancers and is the second leading cause of death after lung cancer, despite significant advances in the treatment of this condition. In 2012, more than 55,000 deaths from this disease occurred in the United States and about 214,000 deaths were registered in Europe. In Romania, in 2012 colorectal cancer occupies the second place among adult cancers, both in terms of incidence $(10,256$ new cases) and mortality (approximately 5,500 deaths) (1).

The main cause of death in patients with colorectal cancer is metastatic disease $(2,3)$. Most often, CRC metastases arise in the liver $(66 \%)$ (4), with the following locations in the order of frequency being peritoneal (15\%), pulmonary (10\%) and bone (1.9\%) (5).

In the past three decades, it has been found that for patients with colorectal hepatic-only metastases (CHMs), the treatment that provides the longest survival (and even the cure in some patients) is hepatic resection associated with adjuvant oncologic treatment $(6,7)$.

For a long time, the presence of extrahepatic metastases (CEMs) was an absolute contraindication to surgery in patients with hepatic and extrahepatic colorectal metastases (CHEHMs).

In the last decade, some authors reported favorable survival results in selected patients with CHEHMs, in which complete resection of all metastatic disease (8-11) could be performed. Currently, several centers consider that the presence of CEMs is no longer an absolute contraindication to liver resection (if complete resection of hepatic and extrahepatic disease can be performed), extrahepatic disease representing only a poor prognostic factor for patients with CHMs. Thus, in some series reported to date, were observed overall survival (OS) rates at 5 years ranging from 26 to $28 \%(12,13)$, significantly higher than those recorded in patients receiving only palliative oncologic therapy (the best chemotherapy treatment can offer a median survival of up to 12-13 months and a 5 years survival of $1 \%)(14,15)$.
The purpose of this study is to present the results achieved by the resection of hepatic and extrahepatic metastases in patients with CHEHMs operated in "Dan Setlacec" Centre of General Surgery and Liver Transplantation of Fundeni Clinical Institute within a period of 20 years and to identify prognostic factors that correlate with longer survival in these patients.

\section{Method}

Retrospectively analysis was performed in 678 patients with CHMs resected in "Dan Setlacec" Center of General Surgery and Liver Transplantation between April 1996 and March 2016.

Of these, 605 had liver only colorectal metastases (CHMs group), and 73 patients had both hepatic and extrahepatic metastases (CHEHMs group). Only patients with extrahepatic metastases diagnosed at the same time as liver metastases and who had histologically proven metastases were included in the latter group. Also in this group were included patients who developed local colorectal recurrence (after previous resection of the primary tumor) at the time of CHMs diagnosis.Morbidity, mortality and survival rates were calculated for each of the two groups (CHMs group and CHEHMs group) and then compared to find if the differences were statistically significant.

In the CHEHMs group, survival rates were compared between patients undergoing complete resection of metastatic burden (R0 group) and patients undergoing incomplete resection of metastatic disease (R1/R2). In the $\mathrm{R} 0$ group, it was also performed a comparative analysis of OS based on the following parameters: location of the primary tumor, $\mathrm{T}$ status, $\mathrm{N}$ status, number of liver metastases, maximum CLMs diameter, neoadjuvant chemotherapy, extent of hepatectomy, the location of extrahepatic disease and the time period of the diagnosis (1996-2004 vs 2005-2016).

The data were obtained from hospital charts, discharge letters from other hospitals (for patients undergoing primary tumor resection in other hospitals), operation database of 
"Dan Setlacec" Centre of General Surgery and Liver Transplantation from Fundeni Clinical Institute,as well as from the computerized database for evidence of patients with liver resections.

Postoperative morbidity was reported as any deviation from the normal postoperative course and was graded according to DindoClavien grading system of postoperative complications. In patients who developed more than one complication, it was reported only the complication with higher DindoClavien grade.

Postoperative mortality was defined as the death of a patient during hospitalization or within the first 30 days after hepatectomy.

The morbidity and mortality rates were compared between different groups of patients by Chi-square test or Fischer's exact test.

OS was defined as the interval between the liver resection and the last follow-up or the date of the patient's death.

Patients who died postoperatively were excluded from survival analysis as well as patients who were lost at follow-up.

The 1-, 3- and 5-year OS rates and median survival were estimated with a Kaplan-Meyer test.

The OS rates were compared between certain groups of patients by Log-rank test.

Differences were considered to have statistical significance when $\mathrm{p}<0.05$.

In some patients, reliable data were not available for certain parameters. That lack of data occurs mainly in patients treated for their primary tumors in other hospitals or those who were not followed in our institution.

For statistical analysis SPSS Statistics 19 was used.

\section{Results}

Out of 678 patients included in the study, 605 had CHMs (3 of them were lost at follow-up) and 73 patients had CHEHMs.

In CHEHMs group, the location of extrahepatic disease and completeness of metastases resection are showed in Table 1.

In CHEHMs group the morbidity rate was $45,2 \%$ (33/73 patients), which was not statistically significant higher than those observed in CHMs group $(38.37 \%$, p value $=0.3096)$. Also, mortality rate was not statistically significant higher in CHEHMs group (5.4\%) than in CHMs group $(2.6 \%-p$ value $=0.2587)$. In CHEHMs group, all the patients who died posoperativelly underwent major hepatectomies. Thus, in CHEHMs group, the mortality rate of patients who underwent major hepatectomy was $26,6 \%$ (4/15 patients), while in patients with minor liver resections the mortality rate was $0 \%(p$ value $=0.0013)$. Two out of these 4 patients died due to postoperative liver failure in 1996 and 1997 and no one patient died during the last 7 years of the study.

In the CHMs group, OS rates at 1-,3- and 5 years were $88.1 \%, 51.8 \%$ and $30.9 \%$ respec- $^{-}$ tively, with a median survival of 39 months. In the CHEHMs group, OS rates at 1-, 3- and 5 years were $68.1 \%, 19.2 \%$ and $9.2 \%$, respectively, with a median survival of 19 months. The OS rates were statistically significant higher in the CHMs group than in the CHEHMs group (p value <0.001) (Table 2, Fig. 1).

Even in patients undergoing $\mathrm{R} 0$ resection, the OS rates achieved in CHEHMs group were significantly lower than those achieved in CHMs group (median survival 20 months vs 39 months, respectivelly; $p$ value $<0.0001$ ) (Table 3, Fig. 2).

Table 1. Location of extrahepatic disease and completeness of resection (CHEHMs group)

\begin{tabular}{lccc}
\hline Locations of extrahepatic disease & Number of patients & Number of Ro & Number of R1/R2 \\
\hline Lymph nodes (hepatic pedicel,celiac trunk, para-aortic) & 20 & 18 & 2 \\
\hline Ovaryand Lung & 12 & 6 & 6 \\
\hline Peritoneum & 20 & 12 & 11 \\
Local Recurrence & 12 & 9 & 0 \\
\hdashline Other metastatic locations & 9 & 6 & 3 \\
(spleen, adrenal, bone, other lymph nodes) & & & \\
\hline
\end{tabular}


Table 2. Comparative survival CHMs group vs. CHEHMs group

\begin{tabular}{lcccc}
\hline Groups & Number of patients & Number of death events & Median [IC95\%] (Month) & p value \\
\hline CHEHMs & 69 & 61 & $19[15.744-22.256]$ & $<0.0001$ \\
\hline CHMs & 587 & 418 & $39[35.596-42.404]$ & \\
\hline
\end{tabular}

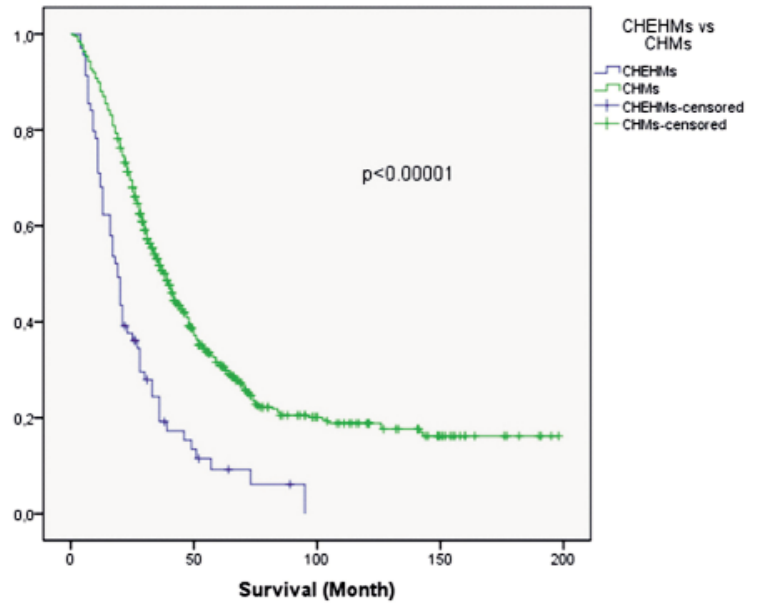

Figure 1. Comparative survival CHEHMs group vs CHMs group

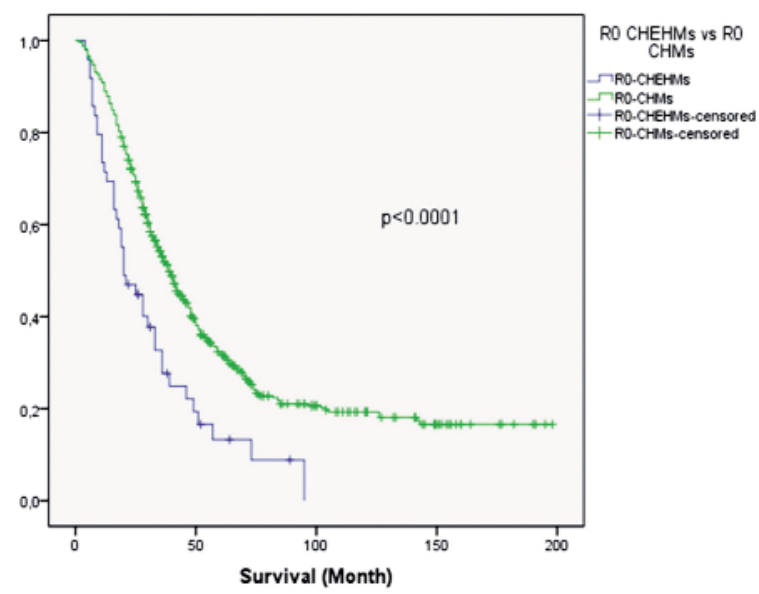

Figure 2. Comparative survival between patients undergoing R0 resection (CHEHMs group vs CHMs group)

Table 3. Comparative survival between patients undergoing RO Resection (CHEHMs group vs CHMs group)

\begin{tabular}{lcccc}
\hline Ro Resection & Number of patients & Number of events(death) & Median [IC95\%] (Month) & p value \\
\hline CHEHMs & 49 & 41 & $20[11.844-28.156]$ & $<0.0001$ \\
\hline CHMs & 571 & 404 & $39[35.334-42.666]$ & \\
\hline
\end{tabular}

Table 4. Comparative Survival of patients with CHEHMs undergoing R0 vs R1/R2 resection

\begin{tabular}{lcccccc} 
Completeness of resection & 1-year (\%) & 3-years (\%) & 5-years (\%) & Median[IC95\%] (Month) & p value \\
\hline R0 & 71.4 & 27.7 & 13.3 & $20[11.844-28.156]$ & 0.004 \\
\hline R1/R2 & 60 & 0 & 0 & $13[11.546-14.454]$ & \\
\hline
\end{tabular}

In CHEHMs group, the 1-, 3- and 5-year OS rates of patients undergoing $\mathrm{R} 0$ resection were $71,4 \%, 27,7 \%$ and $13,3 \%$, respectivelly, with a median OS of 20 months. The 1- and 3-year OS rates achieved by the patients who underwent $\mathrm{R} 1 / \mathrm{R} 2$ resection were $60 \%$ and $0 \%$, respectivelly and the median survival was 13 months (significantly lower than those observed in R0 patients $-\mathrm{p}$ value $=0.004)$ (Table 4, Fig. 3).

In order to identify certain factors related to the primary tumor or liver metastases that significantly influence OS in patients with CHEHMs undergoing $\mathrm{R} 0$ resection, it was

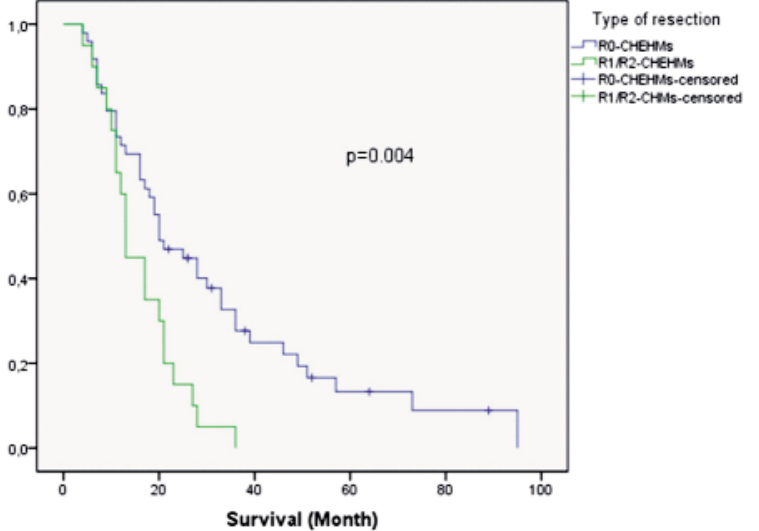

Figure 3. Survival curves of patients with CHEHMs undergoing $\mathrm{R} 0$ vs $\mathrm{R} 1 / \mathrm{R} 2$ resection 
Table 5. Comparative OS depending on specific parameters related to the primary tumor, CHMs, neo-adjuvant chemotherapy and period of diagnosis

\begin{tabular}{|c|c|c|c|c|c|}
\hline Variables & $\begin{array}{c}\text { 1-year OS } \\
(\%)\end{array}$ & $\begin{array}{c}\text { 3-year OS } \\
(\%)\end{array}$ & $\begin{array}{c}\text { 5-years OS } \\
(\%)\end{array}$ & $\begin{array}{l}\text { Median survival } \\
\text { (months) }\end{array}$ & p value \\
\hline Primary tumor location & & & & & 0.522 \\
\hline Rectum & 76.9 & 43.1 & 14.4 & 28 & \\
\hline Colon & 69.4 & 23.7 & 12.7 & 20 & \\
\hline T status & & & & & 0.705 \\
\hline $\mathrm{T} 2$ & 80 & 20 & 20 & 33 & \\
\hline T3 & 75 & 42.9 & 19 & 19 & \\
\hline T4 & 61.5 & 38.5 & 0 & 20 & \\
\hline N status & & & & & 0.719 \\
\hline NO-N1 & 71.6 & 47.6 & 23.8 & 28 & \\
\hline N2 & 70.6 & 33.6 & 16.8 & 21 & \\
\hline Maximum CLMs diameter & & & & & 0.226 \\
\hline$<5 \mathrm{~cm}$ & 77.4 & 39.6 & 19.8 & 21 & \\
\hline$\geq 5 \mathrm{~cm}$ & 60 & 13.3 & 6.7 & 18 & \\
\hline Number of metastases & & & & & 0.036 \\
\hline $1-3$ & 73.8 & 30.8 & 14.8 & 25 & \\
\hline$\geq 4$ & 57.1 & 0 & 0 & 16 & \\
\hline Location of CLMs & & & & & 0.507 \\
\hline Unilobar & 68.4 & 25.5 & 12.8 & 20 & \\
\hline Bilobar & 90 & 24 & 0 & 25 & \\
\hline Extent of hepatectomy & & & & & 0.048 \\
\hline Minor resection & 73.2 & 31.6 & 15.1 & 28 & \\
\hline Major resection & 62.5 & 0 & 0 & 16 & \\
\hline Neo-adjuvant chemotherapy & & & & & 0.792 \\
\hline Yes & 73.3 & 25 & 25 & 19 & \\
\hline No & 69.7 & 29.8 & 8.5 & 29 & \\
\hline Time period & & & & & 0.017 \\
\hline $1996-2004$ & 50 & 0 & 0 & 11 & \\
\hline $2005-2016$ & 75.6 & 33.5 & 16.1 & 28 & \\
\hline
\end{tabular}

performed a comparative analysis between subgroups of patients.

No one factor is related to the primary tumor influences OS in a significantly manner (Table 5).

Among the factors related to the liver metastases, the number of $\mathrm{CHMs}$ significantly impacts OS. Thus, in patients with 1-3 CHMs, the $1^{-}, 3^{-}$and 5-year OS rates were $73.8 \%$, $30.8 \%$ and $14.8 \%$, respectively, while in patients with 4 or more CHMs, there were no survivors at 3 years ( $p$ value $=0,036)($ Table 5, Fig. 4) .

Another factor that significantly influences OS was the extent of liver resection. The patients who required a major hepatectomy achieved a significantly lower OS than those undergoing a minor one $(p$ value $=0.048)$ (Table 5, Fig. 5).

In the first period of time (1996-2004), the $1^{-}$and $3^{-}$year OS rates were $50 \%$ and $0 \%$, respectivelly, while in the second period of time

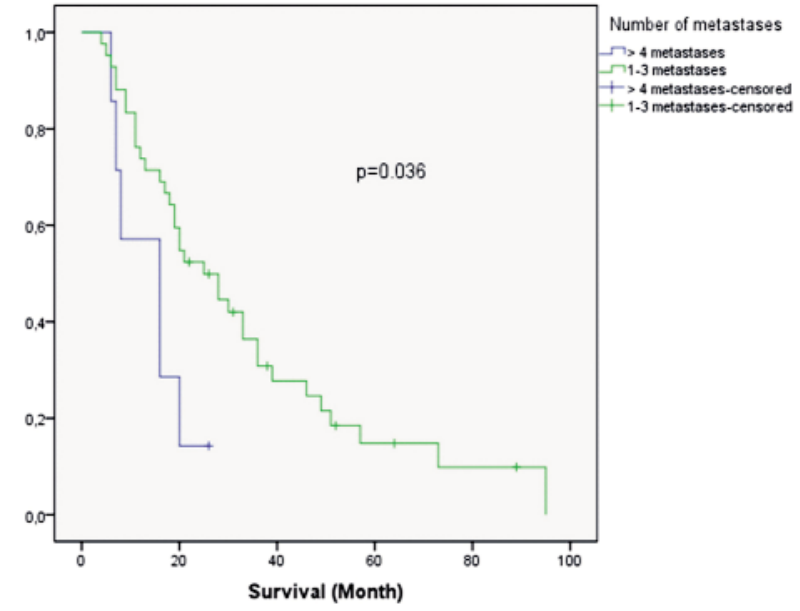

Figure 4. Comparative survival between number of metastases

(2005-2016) the 1-, 3- and 5-year OS rates were $75.6 \%, \quad 33.5 \%$ and $16.1 \%$, respectivelly $(\mathrm{p}=0.017)$ (Fig. 6, Table 5).

Neo-adjuvant chemotherapy did not signifi- 


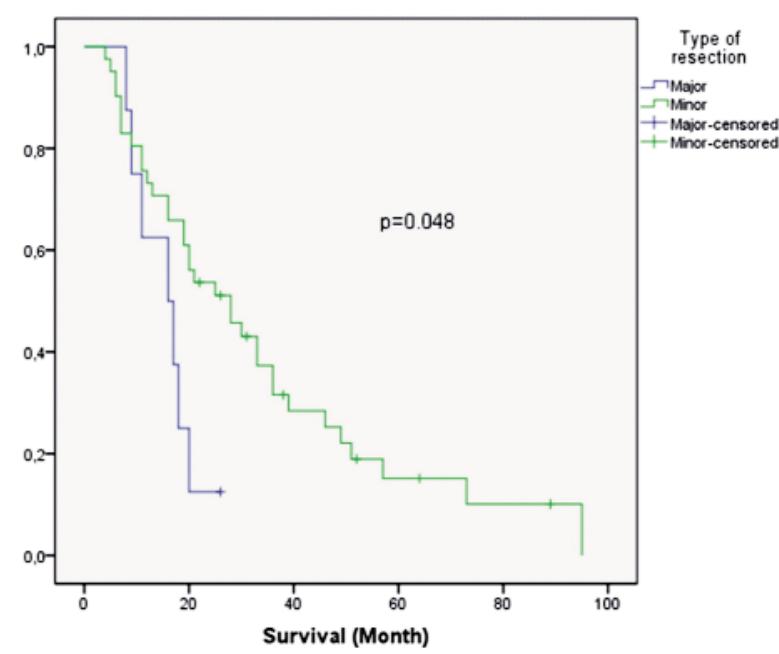

Figure 5. Comparative survival between type of resection (Major resection vs Minor resection)

cantly increased OS in this group of patients (the difference between patients who received neo-adjuvant chemotherapy and those who did not receive was not statistically significant $\mathrm{p}$ value $=0.792)($ Table 5) .

In CHEHMs group, the patients who underwent $\mathrm{R} 0$ resection were divided in 4 subgroups, depending on the location of extrahepatic disease (ovary and lung, peritoneum, lymph nodes and local recurrence). The OS rates were calculated for each of these subgroups. The other patients who presented multiple locations of extrahetic disease or other location of metastases (e.g. spleen, bone) were not included in this analysis due to the very small number of patients in such subgroups.

In „ovar and lung” metastases patients, the 1-, 3- and 5-year OS rates were 80\%, 20\% and $20 \%$, respectivelly, with median survival of 28 months. In „peritoneum” metastases patients, the $1^{-}, 3^{-}$and 5 -year OS rates were $72.7 \%$, $36.4 \%$ and $0 \%$, respectivelly, with median survival of 20 months. In „local recurrence”

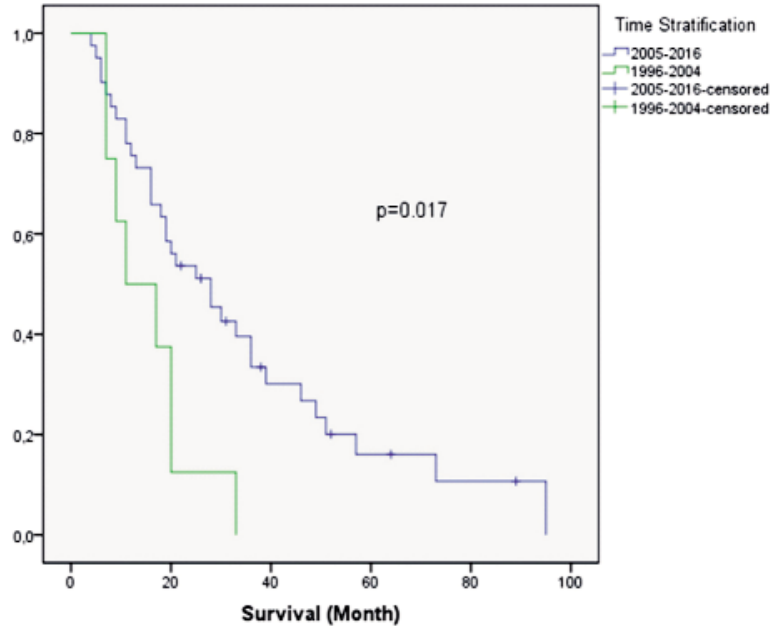

Figure 6. Comparative survival related to period of hepatectomy (1996-2004 vs 2005-2016)

patients, the 1-, 3- and 5-year OS rates were $75 \%, 10.4 \%$ and $0 \%$, respectivelly, with median survival of 19 months.

In „lymph nodes" metastases patients, the 1-, 3- and 5- year OS rates were $56.3 \%, 28.1 \%$ and $14.1 \%$, respectivelly, with median survival of 13 months.

The survival rates were not statistical significantly different between these four subgroups of patients $(\mathrm{p}$ value $=0.413)($ Table 6$)$.

\section{Discussion}

By the early 2000s, the presence of extrahepatic metastases was an absolute contraindication to liver resection in patients with CHMs. Thus, the only treatment recommended for these patients was palliative chemotherapy alone $(16,17)$.

Even now, the presence of extrahepatic metastases is considered a more advanced stage of the disease, with a poorer survival expectancy. By this reason, in the $7^{\text {th }}$ Edition of

Table 6. OS rates of patients with CHEHMs, depending on the extrahepatic disease location

\begin{tabular}{lccccc}
\hline Variables & 1-year (\%) & 3-years (\%) & 5-years (\%) & Median survival (Month) & p value \\
\hline Ovar and Lung & 80 & 20 & 20 & $28[21.559-34.441]$ & 0.413 \\
\hline Peritoneum & 72,7 & 36,4 & 0 & $20[.000-41.579]$ & \\
\hline Local recurrence & 75 & 10,4 & 0 & $19[12.210-25.790]$ \\
\hline Lymph nodes & 56,3 & 28,1 & 14,1 & $13[3.200-22.800]$ & \\
\hline
\end{tabular}


AJCC staging system, patients with metastatic colorectal cancer were divided in two groups (IVA - one metastatic organ/site and IVB - more than one metastatic site), with lower survival rates for the later (18).

However, some retrospective studies published in the late 1990s revealed unexpectedly long survival in some patients with CHEHMs $(8,19,20)$.

For this reason, in the early $2000 \mathrm{~s}$, few authors reviewed the results achieved by curative-intent surgery in their patients operated for concomitant hepatic and extrahepatic metastases from colorectal cancer. In 2003, Elias et al. reported (in a study of 111 patients with CHEHMs) a 5-year overall survival rate of $20 \%$ (10).

Gradually, more and more centers specialized in oncologic surgery performed resection of liver metastases and extrahepatic disease in selected patients with CHEHMs (13,21). In present, in LiverMetSurvey (an international registry including more than 26000 patients with CHMs who were scheduled for curative-intent surgery), the 5-year OS rate of patients undergoing resection of hepatic and extrahepatic metastases was $22 \%$ (22). For these reasons, currently, the presence of concomitant extrahepatic metastases is no longer considered an absolut contraindication for resection of liver metastases, if extrahepatic disease can be entirely removed $(11,13,23,24)$.

The results presented in this study also support the complete resection of the entire metastatic burden as a prerequisite condition to achieve favourable long-term outcomes, since there were no survivors at 3 years following incomplete resections (R1/R2). The 5 -year OS rate (13.3\%) reported in this study in patients who underwent complete resection (R0) of hepatic and extrahepatic disease is more than two times higher than the 5-year OS (6\%) reported by LiverMetSurvey in patients with CHMs who were not resected (22). Furthermore, a recent paper revealed that in the 678 patients undergoing liver resection for CHMs in "Dan Setlacec" Centre of General Surgery and Liver Transplantation from Fundeni Clinical Institute, Bucharest,
R1/R2 resection was an independent prognostic for poor OS, while concomitant extrahepatic disease was not identified as an independent prognostic factor in multivariate analysis (25). These results support the concurrent resection of hepatic and extrahepatic metastases in well-selected patients, if complete resection could be achieved.

However, concerns regarding the safety and oncologic benefit of hepatic and extrahepatic disease resection still persist and the indications and limits of surgical approach are not well established, yet, even in patients who could underwent $\mathrm{R} 0$ resections.

Historically, concerns regarding the safety of such an extensive operation have been raised, but most series reported in the last decade revealed that the short-term results achieved in these patients were similar to those observed in patients undergoing surgery for liver-limited metastases $(10,26,27)$. A similar trend was also observed in the present series, with no significant differences in morbidity and mortality rates between CHMs group and CHEHMs group, except for the patients undergoing major hepatectomies in the early period of this study. All the patients from this study who died postoperatively underwent major liver resections (for more than 4 CHMs larger than $5 \mathrm{~cm}$ ) and 3 out of 4 patients underwent simultaneous resection of the primary tumor and hepatic and extrahepatic metastases. Since 2010, simultaneous resection of colorectal tumor and CHEHMs was avoided, especially in patients requiring major hepatectomies; consequently, during the last years no one patient died postoperatively.

Moreover, the long-term results achieved in CHEHMs patients who underwent major hepatectomies were poor in this study, with no one survivor beyond 3 years. The extent of liver resection could represent a surrogate parameter for the tumor load of the liver, major liver resections being performed usually due to the high number and/or large diameter of CHMs. By this point of view, the poor OS rates achieved in patients who underwent major hepatectomies may reflect the poor outcome of patients with high volume liver disease. This 
fact has been recently suggested by J. Chakedis et al, in a review article on current problems in colorectal liver metastases (26).

Similar poor results were observed in patients presenting four or more liver metastases. In such patients, the OS rates achieved by complete resection of CHEHMs were significantly lower than in patients with up to 4 liver metastases. Comparable results were reported by D. Elias et al, who concluded that the presence of more than five liver metastases still represents a contraindication to hepatic resection in the setting of concomitant hepatic and extrahepatic metastases $(10,12)$. Similarly, R. Adam et al revealed that the presence of six or more CHMs is a strong negative prognostic factor in patients with CHEHMs (28).

Besides these prognostic factors, the location of the extrahepatic disease seems to significantly influence the long-term outcomes. Thus, most studies on this subject revealed that the presence of portal/retroperitoneal lymph node metastases is a strong predictor of poor outcome (21, 29-34). Although in our study the difference in OS was not statistically significant lower in these patients compared to other locations of extrahepatic disease, they experienced the lowest median survival (13 months) after R0 surgery. By contrary, the patients with lung or ovarian metastases experienced the most prolonged survivals in our series, representing the most suitable candidates for resection of hepatic and extrahepatic metastases from colorectal cancer. This observation has also been reported since 2000 s by other groups $(27,35)$.

In present, lung-limited metastases of colorectal origin benefit by a similar therapeutic strategy as liver-limited metastases, their resection being considered the treatment of choice, able to significantly increase survival of the patients. Some authors consider that the survival benefit achieved by resection of lung metastases is due to their favorable biologic behaviour. Moreover, in a recent study, Y. Mise et al revealed that in patients with concomitant liver and lung metastases, resection of liver metastases only was associated with signifi- cantly worse survival than those of patients with resection of liver and lung metastases. The 3- and 5-year OS rates of patients with liver resection only ( $42.9 \%$ and $13.1 \%$, respectively) were better than those of patients treated with palliative oncologic therapy $(14.1 \%$ and $1.6 \%$, respectively; $p<0.01)$. By this reason, the authors concluded that in selected patients (K-ras wild-type, primary tumor located in the colon) even resection of liver metastases in the setting of unresectable lung metastases should be considered (36). Such results may be explained by the relative indolent growth of lung metastases, but also by the more effective oncologic treatment available in present (cytotoxic agents and targeted therapies). In our centre, in the last decade, the use on a large scale of more efficient oncological therapies (Oxaliplatin, Irinotecan, Bevacizumab and Cetuximab) could also explain the better OS rates achieved in second period of the present study.

The role of modern oncological therapy in selecting patients for resection of hepatic and extrahepatic disease was also emphasized by some authors $(10,12)$, who recommended in patients with poor prognostic factors the use of neo-adjuvant chemotherapy (28). However, the present study, as well as other studies, did not reveal that neo-adjuvant chemotherapy will translate in significantly increased OS rates. Moreover, D. Carpizo et al showed that neoadjuvant chemotherapy was independently associated with a worse survival (13). This result may be induced by a selection bias, as most centres recommend preoperative use of chemotherapy especially in patients with more advanced disease (that portend a dismal prognosis). This contradiction between the postulated advantages of neo-adjuvant chemotherapy and the lack of proven benefit (based on the papers published until now) could be explained by the retrospective type of the studies, the selection bias for therapy allocation and the small number of patients included in these studies.

\section{Conclusion}

In conclusion, this study, nevertheless presenting 
all the above-mentioned limitations, was able to confirm that complete resection of metastases could significantly prolong survival in selected patients with CHEHMs. Although these patients have a low chance of cure even by $\mathrm{R} 0$ resections, they may benefit from an aggressive onco-surgical treatment strategy that includes surgical resection of all metastases. The patients requiring minor liver resection for less than four liver metastases benefit the most from complete resection of hepatic and extrahepatic disease.

\section{References}

1. http://gco.iarc.fr/today/home.

2. McLoughlin JM JE, Malafa M. Resection of colorectal liver metastases: current perspectives. Cancer Control 2006;13(1):32-41. 2006:32-41.

3. Faivre J, Manfredi S, Bouvier AM. Epidemiology of colorecta cancer liver metastases. Bull Acad Natl Med. 2003;187(5):815-22.

4. Manfredi S, Lepage C, Hatem C, Coatmeur O, Faivre J, Bouvier AM. Epidemiology and management of liver metastases from colorecta cancer. Ann Surg. 2006;244(2):254-9.

5. Capussoti L. Surgical Treatment of Colorectal Liver Metastases. Milan. Epidemiology and natural history In: Capussotti L, editor. 2011:1-6.

6. Belghiti J. Synchronous and resectable hepatic metastases of colorectal cancer: should there be a minimum delay before hepatic resection?. Ann Chir. 1990;44(6):427-9; discussion 9-32.

7. Bismuth H, Castaing D, Traynor 0 . Surgery for synchronous hepatic metastases of colorectal cancer. Scand J Gastroenterol Suppl. 1988; 149:144-9.

8. Nordlinger B JD, Balladur P, Vaillant JC, Paris F. Surgical resection of hepatic metastases. Comments on the results of the multicentric retrospective study by the French Association of Surgery. In Nordlinger B, Jaeck D, editors Treatment of hepatic metastases of colorectal cancer. 1992:147-57.

9. Byam J, Reuter NP, Woodall CE, Scoggins CR, McMasters KM, Martin RC. Should hepatic metastatic colorectal cancer patients with extrahepatic disease undergo liver resection/ablation? Ann Surg Oncol. 2009:16(11):3064-9.

10. Elias D, Ouellet JF, Bellon N, Pignon JP, Pocard M, Lasser P. Extrahepatic disease does not contraindicate hepatectomy for colorectal liver metastases. Br J Surg. 2003:90(5):567-74.

11. William J. Hadden PRdR, Kai Brown, Anubhav Mittal, Jaswinder S. Samra, and Thomas J. Hugh. Resection of colorectal liver metastases and extra-hepatic disease: a systematic review and proportional meta-analysis of survival outcomes. HPB ( Oxford). 2016.

12. Elias D, Liberale G, Vernerey D, Pocard M, Ducreux M, Boige V, et al. Hepatic and extrahepatic colorectal metastases: when resectable, their localization does not matter, but their total number has a prognostic effect. Ann Surg Oncol. 2005;12(11):900-9.

13. Carpizo DR, Are C, Jarnagin W, Dematteo R, Fong Y, Gonen M, et al. Liver resection for metastatic colorectal cancer in patients with concurrent extrahepatic disease: results in 127 patients treated at a single center. Ann Surg Oncol. 2009;16(8):2138-46.

14. Ferrarotto R, Pathak P, Maru D, Agarwal A, Overman M, Hoff PM, et al Durable complete responses in metastatic colorectal cancer treated with chemotherapy alone. Clin Colorectal Cancer. 2011:10(3):178-82.

15. Simmonds PC. Palliative chemotherapy for advanced colorectal cancer: systematic review and meta-analysis. Colorectal Cancer Collaborative Group. BMJ. 2000;321(7260):531-5.

16. Stangl R A-HA, Charnley RM, Scheele J. Factors influencing the natural history of colorectal liver metastases. Lancet. 1994:1405-10.

17. Adam R, Haller DG, Poston G, Raoul JL, Spano JP, Tabernero J, et al.
Toward optimized front-line therapeutic strategies in patients with metastatic colorectal cancer--an expert review from the International Congress on Anti-Cancer Treatment (ICACT) 2009. Ann Oncol. 2010; 21(8):1579-84.

18. Edge SB, Compton CC. The American Joint Committee on Cancer: the 7 th edition of the AJCC cancer staging manual and the future of TNM. Ann Surg Oncol. 2010:17(6):1471-4.

19. Scheele J, Stang R, Altendorf-Hofmann A, Paul M. Resection of colorectal liver metastases. World J Surg. 1995;19(1):59-71.

20. Minagawa M, Makuuchi M, Torzilli G, Takayama T, Kawasaki S, Kosuge $\mathrm{T}$, et al. Extension of the frontiers of surgical indications in the treatment of liver metastases from colorectal cancer: long-term results. Ann Surg. 2000;231(4):487-99.

21. Pulitano $C$, Bodingbauer $M$, Aldrighetti $L$, de Jong MC, Castillo F, Schulick RD, et al. Liver resection for colorectal metastases in presence of extrahepatic disease: results from an international multi-institutional analysis. Ann Surg Oncol. 2011;18(5):1380-8.

22. 2015 LSLSD. https://livermetsurvey manettis org:8443/ SASStored Process/do. 2015

23. Pulitano C, Bodingbauer M, Aldrighetti L, Choti MA, Castillo F, Schulick $\mathrm{RD}$, et al. Colorectal liver metastasis in the setting of lymph node metastasis: defining the benefit of surgical resection. Ann Surg Oncol. 2012;19(2):435-42.

24. Oussoultzoglou E, Romain B, Panaro F, Rosso E, Pessaux P, Bachellier $P$, et al. Long-term survival after liver resection for colorectal liver metastases in patients with hepatic pedicle lymph nodes involvement in the era of new chemotherapy regimens. Ann Surg. 2009;249(6): 879-86.

25. Sorin Alexandrescu* AD, Narcis Octavian Zarnescu, Zenaida Ionel, Cristian Zlate, Doina Hrehoret, Vladislav Brasoveanu, Razvan Grigorie, Florin Botea,, Mihnea Ionescu, Irinel Popescu. Prognostic factors for survival after resection of liver metastases from colorectal cancer: a single institution analysis of 655 cases. 2017.

26. Jeffery Chakedis MHS, Eliza W. Beal, Tasha Hughes, Heather Lewis, Anghela Paredes,Mazen Al-Mansour, Steven Sun, Jordan M. Cloyd, Timothy M. Pawlik. Update on Current Problems in Colorectal Liver Metastasis. Current Problems in Surgery. 2017.

27. Carpizo DR, D'Angelica M. Liver resection for metastatic colorectal cancer in the presence of extrahepatic disease. Ann Surg Oncol. 2009:16(9):2411-21.

28. Adam R, de Haas RJ, Wicherts DA, Vibert E, Salloum C, Azoulay D, et al. Concomitant extrahepatic disease in patients with colorectal liver metastases: when is there a place for surgery? Ann Surg. 2011; 253(2):349-59.

29. Leung U, Gonen M, Allen PJ, Kingham TP, DeMatteo RP, Jarnagin WR, et al. Colorectal Cancer Liver Metastases and Concurrent Extrahepatic Disease Treated With Resection. Ann Surg. 2016.

30. Jaeck D, Nakano H, Bachellier P, Inoue K, Weber JC, Oussoultzoglou E, et al. Significance of hepatic pedicle lymph node involvement in patients with colorectal liver metastases: a prospective study. Ann Surg Oncol. 2002;9(5):430-8.

31. Pindak D, Pavlendova J, Tomas M, Dolnik J, Duchon R, Pechan J. Selective versus routine lymphadenectomy in the treatment of liver metastasis from colorectal cancer: a retrospective cohort study. BMC Surg. 2017;17(1):34.

32. Rodgers MS, McCall JL. Surgery for colorectal liver metastases with hepatic lymph node involvement: a systematic review. Br J Surg 2000;87(9):1142-55

33. Poston GJ, Adam R, Alberts S, Curley S, Figueras J, Haller D, et al. OncoSurge: a strategy for improving resectability with curative intent in metastatic colorectal cancer. J Clin Oncol. 2005;23(28):7125-34.

34. Adam R, de Haas RJ, Wicherts DA, Aloia TA, Delvart V, Azoulay D, et al. Is hepatic resection justified after chemotherapy in patients with colorectal liver metastases and lymph node involvement? J Clin Oncol. 2008:26(22):3672-80.

35. Headrick JR, Miller DL, Nagorney DM, Allen MS, Deschamps C, Trastek VF, et al. Surgical treatment of hepatic and pulmonary metastases from colon cancer. Ann Thorac Surg. 2001;71(3):975-9.

36. Mise Y, Kopetz S, Mehran RJ, Aloia TA, Conrad C, Brudvik KW, et al. Is complete liver resection without resection of synchronous lung metastases justified? Ann Surg Oncol. 2015;22(5):1585-92. 